\title{
Molecular identification of Sarcocystis lutrae (Apicomplexa: Sarcocystidae) from the raccoon dog, Nyctereutes procyonoides, and the common raccoon, Procyon lotor, in the Czech Republic
}

Ondřej Máca ${ }^{1,2^{*}}$ (1)

\begin{abstract}
Background: Apicomplexan parasites of the genus Sarcocystis have an obligate two-host life-cycle and comprise about 200 species, which infect different cold- and warm-blooded hosts, including humans. Recently, morphological and molecular studies of sarcocysts in broadly spread carnivore hosts have been on the rise. The description of muscular tissues infection by Sarcocystis in the raccoon dog and the common raccoon from the Czech Republic is herein presented.
\end{abstract}

Methods: During January-August 2019, 15 raccoon dogs and 1 common raccoon were examined from 5 districts (Česká Lípa, Liberec, Mladá Boleslav, Trutnov and Ústí nad Labem) of the Czech Republic. Muscle parts (diaphragm, forearm, hind-limb, tongue and heart) were examined in wet preparations under compression by light microscopy. After finding Sarcocystis sp., morphological characteristics and molecular analyses of 185 rRNA, 285 rRNA, ITS1 and cox1 loci were used to identify the species.

Results: Sarcocysts were detected and identified in 1 out of 15 raccoon dogs and in the single common raccoon. Preferential infection sites were diaphragm and tongue, followed by forearm and hind limb. To our knowledge, this is the first identification of microscopic sarcocysts by multi-locus genetic analysis from both host species. Molecular analyses revealed 100\% similarity at 18S rRNA, 28S rRNA, and cox1 genes with S. lutrae for both hosts and 98-100\% identity at the ITS1 region of the isolate from the common raccoon.

Conclusions: Both widely distributed non-indigenous wild carnivores represent new intermediate host records for S. lutrae and the first report of this parasite in a member of the family Procyonidae, but still with an unknown natural definitive host. Molecular data revealed that this parasite species appears more closely related to the Sarcocystis spp. using raptorial birds as definitive hosts. Therefore, further studies aimed at its identification, including the complete life-cycle, remain necessary.

Keywords: Sarcocystis /utrae, Common raccoon, Raccoon dog, Wildlife, Molecular characterization, Czech Republic

*Correspondence: biola.biola@seznam.cz

1 Department of Pathology and Parasitology, State Veterinary Institute

Prague, Sídlištní 136/24, Prague 6165 03, Czech Republic

Full list of author information is available at the end of the article

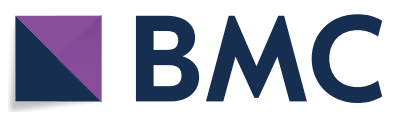

(c) The Author(s) 2020. This article is licensed under a Creative Commons Attribution 4.0 International License, which permits use, sharing, adaptation, distribution and reproduction in any medium or format, as long as you give appropriate credit to the original author(s) and the source, provide a link to the Creative Commons licence, and indicate if changes were made. The images or other third party material in this article are included in the article's Creative Commons licence, unless indicated otherwise in a credit line to the material. If material is not included in the article's Creative Commons licence and your intended use is not permitted by statutory regulation or exceeds the permitted use, you will need to obtain permission directly from the copyright holder. To view a copy of this licence, visit http://creativeco mmons.org/licenses/by/4.0/. The Creative Commons Public Domain Dedication waiver (http://creativecommons.org/publicdomain/ zero/1.0/) applies to the data made available in this article, unless otherwise stated in a credit line to the data. 


\section{Background}

The genus Sarcocystis (Apicomplexa: Sarcocystidae) comprises approximately 200 species that are ranked among the most widespread protozoan infectious agents in domestic and wild animals, as well as humans, which act as intermediate or/and definitive hosts [1]. One of the most relevant Sarcocystis species in recent years is Sarcocystis lutrae that is recognised as a major cause of sarcosporidial infection in the skeletal muscles of carnivores, especially in mustelids (the American mink, Neovison vison; beech marten, Martes foina; European badger, Meles meles; European otter, Lutra lutra; European polecat, Mustela putorius) and less commonly in canids (Arctic fox, Vulpes lagopus; and red fox, Vulpes vulpes) [2-6].

The role of wild terrestrial carnivores in the transmission of infectious diseases continuously requires scientific attention, especially in those widely spread non-indigenous carnivores with the ability to adapt in new habitats, such as the raccoon dog (Nyctereutes procyonoides) (Canidae) and the common raccoon (Procyon lotor) (Procyonidae). These hosts are native to East Asia and North America and have been introduced across Europe, including the Czech Republic, where they have spread zoonotic parasites and other pathogens (e.g. Echinococcus or Trichinella) [7-10].

To date, $P$. lotor has been reported as an important natural intermediate host of $S$. neurona in North America [11], S. kirkpatricki in Illinois, USA [12] and S. cf. sebeki and two additional unnamed species in Germany [13]. On the other hand, Sarcocystis sp. was reported in the Japanese raccoon dog (Nyctereutes procyonoides viverrinus) from Japan [14], but never in N. procyonoides ussuriensis. In none of these reports the parasite has been described molecularly. Therefore, as a part of a study focusing on the evaluation of the diversity of Sarcocystis species in the Czech Republic, raccoon dogs and common raccoons were examined for the occurrence of parasitic infections. Moreover, parasites were for the first time molecularly characterized by using 4 loci, i.e. $18 S$ ribosomal RNA (18S rRNA), $28 S$ ribosomal RNA (28S rRNA), mitochondrial cytochrome $c$ oxidase subunit 1 ( $\operatorname{cox} 1)$ genes and the internal transcribed spacer 1 (ITS1) region.

\section{Methods}

Hunted or road-killed animals were sent to the State Veterinary Institute Prague as part of a monitoring programme during January-August 2019. Muscle samples were taken from 15 raccoon dogs from Česká Lípa, Liberec, Mladá Boleslav, Trutnov, as well as 1 common raccoon from Ústí nad Labem, all in the Czech Republic. Samples were immediately examined through wet mounts and compression methods (28 plots of compressors) for the detection of bradyzoites or sarcocysts of Sarcocystis using a Leica DMLB optical microscope (Leica Microsystems, Wetzlar, Germany) equipped with Nomarski differential interference contrast. Parasites were transferred to an Eppendorf tube for DNA extraction.

Genomic DNA was extracted by glass bead disruption from four isolates of sarcocysts collected from diaphragm or forearm muscles of both host species using the QIAamp ${ }^{\circledR}$ DNA Stool Mini Kit (Qiagen, Hilden, Germany) following the standard protocol suggested by the manufacturer. DNA was stored at $-20{ }^{\circ} \mathrm{C}$ until use in polymerase chain reaction (PCR) assays. The identity of the isolated sarcocysts was assessed based on their morphological aspects and complemented by sequencing of $18 S$ rRNA, $28 S$ rRNA, ITS1 and $\operatorname{cox} 1$ loci. PCR reactions were performed and amplified using primers for the $18 S$ rRNA gene (Fext/Rext; Fint/ Rint) [15], $28 S$ rRNA gene (KL1/LS2R; LS1F/KL3) [16, 17], ITS1 region (18S14F/ITS1FR or SU1F/5.8SR2) $[17,18]$ and cox1 gene (SF1/SR10 or SF1/SR5) [19, 20]. Amplification was carried out in a final volume of $25 \mu \mathrm{l}(20 \mu \mathrm{l}$ of reaction mixture and $5 \mu \mathrm{l}$ of DNA extract) comprising of $1 \times$ Green or Colorless GoTaq $^{\circledR}$ Flexi Buffer, $2.5 \mathrm{mM}$ of $\mathrm{MgCl}_{2}, 0.625 \mathrm{U}_{\text {of }} \mathrm{GoTaq}^{\circledR} \mathrm{G} 2$ Flexi DNA Polymerase (Promega, Madison, Wisconsin, USA), $0.2 \mathrm{mM}$ of dNTP mix (Bioline, London, UK), $0.4 \mu \mathrm{M}$ of each primer, DNA template and nucleasefree water. PCR amplification of isolated DNA samples plus positive and negative controls were performed with the cycling conditions as follows: an initial denaturation step at $95{ }^{\circ} \mathrm{C}$ for $5 \mathrm{~min}$; 35 cycles of $95^{\circ} \mathrm{C}$ for $30 \mathrm{~s}, 43.5-55.5^{\circ} \mathrm{C}$ for $30 \mathrm{~s}, 72{ }^{\circ} \mathrm{C}$ for $1 \mathrm{~min}$; and a final extension step at $72{ }^{\circ} \mathrm{C}$ for $10 \mathrm{~min}$. The nested PCR (18S and $28 S$ rRNA genes) cycling conditions were identical to those used for PCR (ITS1 region and cox 1 gene) amplification. The PCR products were later analysed by electrophoresis in a $1 \%(\mathrm{w} / \mathrm{v})$ agarose gel stained with ethidium bromide and visualized under a UV light. The PCR products were purified using the High Pure PCR Product Purification Kit (Roche Diagnostics, Mannheim, Germany) and sequenced using the sequencing service of Eurofins Genomics (Ebersberg, Germany) from both forward and reverse directions for each isolate. The nucleotide sequences of the four loci derived in this study have been deposited in the GenBank database under the accession numbers MT036248-MT036254. The newly generated sequences were compared with published sequences across the GenBank NCBI database using BLAST analysis (Basic Local Alignment Search Tool). 


\section{Results}

One sarcocyst morphotype (Fig. 1) and several bradyzoites of the genus Sarcocystis were detected in the diaphragm, hind-limb, forearm and tongue muscles in 1 of 15 raccoon dogs (prevalence $=7 \%$; intensity $=1$ sarcocyst per gram) and in the single common raccoon examined $(100 \%$, intensity $=1$ sarcocyst per gram). Hearts of both hosts were negative. Sarcocysts were up to $2260 \mu \mathrm{m}$ long, thin-walled (0.8-1.1 $\mu \mathrm{m}$ thick) and $66 \mu \mathrm{m}$ wide, with a smooth wall and no visible protrusions. Sarcocysts were filled with banana-shaped bradyzoites, measuring 6.8$9.2 \times 1.6-2.4 \mu \mathrm{m}(n=20)$.

Muscular sarcocysts from $N$. procyonoides (one isolate) and P. lotor (two isolates) were successfully identified molecularly and sequenced at each locus. In the former, the length of the generated representative nucleotide sequences was $1593 \mathrm{bp}$ for $18 \mathrm{~S}$ rRNA, $519 \mathrm{bp}$ for $28 S$ rRNA and 880 bp for cox 1 , whereas in the latter the length was $1525 \mathrm{bp}$ for $18 \mathrm{~S}$ rRNA, $1279 \mathrm{bp}$ for $28 \mathrm{~S}$ rRNA, 337 bp for the ITS1 region and 1029 bp for cox 1 . Sequence analysis at four genetic loci identified sarcocysts isolates as $S$. lutrae. Isolated sarcocysts from both host species showed $100 \%$ similarity. At the $18 S$ rRNA and $\operatorname{cox} 1$ genes, the new sequences were $100 \%$ identical to those of S. lutrae from M. meles (Mustelidae) in the Czech Republic (GenBank: MG372102, MG372106) and Lithuania (GenBank: MG272295, MG273670). The new cox 1 sequences were also $100 \%$ identical to those of S. lari (GenBank: MF946584) from Haliaeetus albicilla (Accipitridae) in Norway. At the $28 S$ rRNA gene, the new sequences obtained from $N$. procyonoides $(519 \mathrm{bp})$ and P. lotor (1279 bp) were both $100 \%$ identical to those of $S$. lutrae from M. meles and L. lutra in the Czech Republic (GenBank: MG372104, MG372105), whereas the longer sequence from $P$. lotor differed by a single nucleotide polymorphism at position 891 (from $G$ to A) from sequences obtained from M. meles and L. lutra in Lithuania (GenBank: MG272285, MG272276). A sequence of the highly variable genomic ITS1 region of $S$. lutrae obtained from $P$. lotor was $98-100 \%$ similar to the sequences obtained from $M$. meles in the Czech Republic (GenBank: MG372108) and Lithuania (GenBank: MG272304). Unfortunately, the ITS1 region of the isolate from N. procyonoides could not be successfully sequenced, even upon re-sequencing.

\section{Discussion}

To the best of our knowledge, this is the first worldwide report of S. lutrae parasitizing $N$. procyonoides and $P$. lotor, thus increasing its host spectrum to nine species. Sarcocysts of S. lutrae were previously reported and molecularly characterized in different species of mustelids and canids from the Czech Republic, Latvia,
Lithuania, Norway and Scotland [2-6]. This parasite is the most common species among mustelids, with prevalence ranging between $67-82 \%$ in the European badger (M. meles) from Scotland and the Czech Republic $[3,5]$. In the present survey its prevalence in $N$. procyonoides was low (7\%), although this host probably acts as natural intermediate host, since other canids, such as red foxes ( $V$. vulpes) from Latvia (0.2\%) and Lithuania (2\%) [4], also showed low prevalence. A similar pattern occurs in a congeneric species, $S$. arctica, in red fox ( $V$. vulpes) (prevalence 3.8\%) from the Czech Republic [21]. On the other hand, the single $P$. lotor examined was positive to $S$. lutrae, thus suggesting that the parasite occurs in various hosts, although the sample size should be increased. More data about prevalence and molecular analysis of $S$. lutrae in procyonids are needed to determinate its host spectrum and the role of these hosts in the life-cycle of this parasite.

Our finding of S. lutrae in hind-limb differs from that of Kirillova et al. [4], who found no sarcocysts of this parasite in $294 \mathrm{~N}$. procyonoides from Latvia, even though they examined the same kind of muscle. These differences could be related to the availability of potential hosts and their interactions, regional parasite occurrence, low susceptibility of raccoon dogs to this parasite or to the quality of samples examined (fresh $v s$ autolytic).

The present nucleotide sequences were identical to those of S. lutrae in the European badger and European otter from the Czech Republic, thus indicating that the parasite is spread across the country in various carnivore hosts, at the same time, with some mustelid and canid hosts from other European countries. In order to elucidate the real host spectrum of this parasite, it is important to molecularly characterize those records of Sarcocystis sp. in several intermediate [1] and other

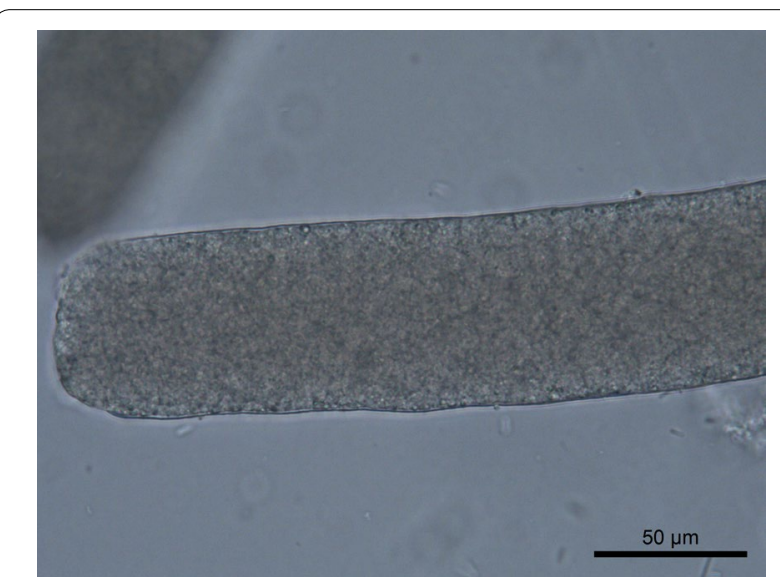

Fig. 1 Sarcocystis /utrae isolated from the hind-limb muscle of Nyctereutes procyonoides (wet mount) 
possible definitive hosts, since the morphology of sarcocysts and bradyzoites is rather similar among species. All published sequences of $S$. lutrae using the $18 S$ rRNA gene share high identity ( $>99 \%$ ) with those of $S$. halieti (GenBank: MF946587) and S. lari (GenBank: MF946588) in the white-tailed sea eagle $(H$. albicilla), S. corvusi (GenBank: JN256117) in the jackdaw (Corvus monedula) and S. columbae (GenBank: HM125054) in the wood pigeon (Columba palumbus), cox1 gene sequences were $100 \%$ identical to S. lari (GenBank: MF946584) and $>99 \%$ to Sarcocystis sp. in Accipiter cooperii (GenBank: KY348756), see also [4]. Therefore, other loci are recommended to distinguish closely related Sarcocystis species where carnivores are intermediate hosts, such as the $28 S$ rRNA gene and ITS1. 285 rRNA gene sequences of S. lutrae were $98 \%$ or less similar to other closely related Sarcocystis species (e.g. S. lari), whose intermediate and definitive hosts are the great black-backed gull (Larus marinus) (GenBank: JQ733509) and white-tailed sea eagle (GenBank: MF946611), respectively. ITS1 showed strong support for the species delimitation [22], since our sequence was $86-92 \%$ similar to S. lari (e.g. GenBank: MF946597). Thus, S. lutrae appears most closely related to species that use medium-to-large size raptorial birds as definitive hosts. Differences in the known sequences of $S$. lutrae are a result of the intraspecific variability, especially within ITS1 [2, 4] and $28 S$ rRNA gene [5], as observed in the present loci from $P$. lotor (GenBank: MT036249 and MT036253). Despite some limitations (unsuccessful ITS1 sequencing), the data allowed to clearly determine that both mammal species are hosts of this parasite.

Thus, $P$. lotor is the first reported procyonid host for $S$. lutrae; this host and N. procyonoides act as intermediate hosts of this parasite.

\section{Conclusions}

There are still gaps in the knowledge of the life-cycle of S. lutrae, although apparently, this species uses several carnivore hosts as intermediate and final hosts, which should be morphologically and molecularly characterized to provide new insights into the spread of this parasite species. Further studies considering predator communities may help determine their role in the introduction and transmission of disease into different wild and farmed populations.

\section{Abbreviations}

cox1: Cytochrome c oxidase subunit 1; ITS1: Internal transcribed spacer 1; PCR: Polymerase chain reaction; rRNA: Ribosomal ribonucleic acid.

\section{Acknowledgements}

The author would like to thank all colleagues from the Pathology and Parasitology Department (SVI Prague), especially technicians E. Dubská, V.
Junová, and O. Doskočil for help with the graphical abstract. Three anonymous reviewers provided valuable comments and suggestions on early versions of the manuscript.

\section{Authors' contributions}

OM conceived and designed the study, performed analyses and wrote the manuscript. The author read and approved the final manuscript.

\section{Funding}

Open access funding was provided by the Faculty of Agrobiology, Food and Natural Resources, Czech University of Life Sciences Prague.

\section{Availability of data and materials}

The sequences generated in the present study were submitted to the GenBank database under the accession numbers MT036248-MT036254.

\section{Ethics approval and consent to participate}

Not applicable.

\section{Consent for publication \\ Not applicable.}

\section{Competing interests}

The author declares that he has no competing interests.

\section{Author details}

${ }^{1}$ Department of Pathology and Parasitology, State Veterinary Institute Prague, Sídlištní 136/24, Prague 6165 03, Czech Republic. ${ }^{2}$ Department of Zoology and Fisheries, Faculty of Agrobiology, Food and Natural Resources, Czech University of Life Sciences Prague, Kamýcká 129, Prague Suchdol 16500 , Czech Republic.

Received: 19 February 2020 Accepted: 27 April 2020

Published online: 06 May 2020

\section{References}

1. Dubey JP, Calero-Bernal R, Rosenthal BM, Speer CA, Fayer R. Sarcocystosis of animals and humans. Boca Raton: CRC Press; 2016.

2. Gjerde B, Josefsen TD. Molecular characterisation of Sarcocystis lutrae n. sp. and Toxoplasma gondii from the musculature of two Eurasian otters (Lutra lutra) in Norway. Parasitol Res. 2015;114:873-86.

3. Lepore T, Bartley PM, Chianini F, Macrae Al, Innes EA, Katzer F. Molecular detection of Sarcocystis lutrae in the European badger (Meles meles) in Scotland. Parasitology. 2017:144:1426-32.

4. Kirillova V, Prakas P, Calero-Bernal R, Gavarāne I, Fernández-García JL, Martínez-González M, et al. Identification and genetic characterization of Sarcocystis arctica and Sarcocystis lutrae in red foxes (Vulpes vulpes) from Baltic States and Spain. Parasit Vectors. 2018;11:173.

5. Máca O. Molecular identification of Sarcocystis lutrae in the European otter (Lutra lutra) and the European badger (Meles meles) from the Czech Republic. Parasitol Res. 2018:117:943-5.

6. Prakas P, Strazdaitè-Žielienè Ž, Rudaitytè-Lukošienè E, Servienè E, Butkauskas D. Molecular identification of Sarcocystis lutrae (Apicomplexa: Sarcocystidae) in muscles of five species of the family Mustelidae. Parasitol Res. 2018:117:1989-93.

7. Beltrán-Beck B, García FJ, Gortázar C. Raccoons in Europe: disease hazards due to the establishment of an invasive species. Eur J Wildl Res. 2011;58:5-15

8. Oksanen A, Siles M, Karamon J, Possenti A, Conraths F, Romig T, et al. The geographical distribution and prevalence of Echinococcus multilocularis in animals in the European Union and adjacent countries: a systematic review and meta-analysis. Parasit Vectors. 2016:9:519.

9. Kärssin A, Häkkinen L, Niin E, Peik K, Vilem A, Jokelainen P, et al. Trichinella spp. biomass has increased in raccoon dogs (Nyctereutes procyonoides) and red foxes (Vulpes vulpes) in Estonia. Parasit Vectors. 2017;10:609.

10. Cybulska A, Skopek R, Kornacka A, Popiołek M, Piróg A, Laskowski Z, et al. First detection of Trichinella pseudospiralis infection in raccoon (Procyon lotor) in central Europe. Vet Parasitol. 2018;254:114-9. 
11. Dubey JP, Howe DK, Furr M, Saville WJ, Marsh AE, Reed SM, et al. An update on Sarcocystis neurona infections in animals and equine protozoal myeloencephalitis (EPM). Vet Parasitol. 2015;209:1-42.

12. Snyder DE, Sanderson GC, Toivio-Kinnucan M, Blagburn BL. Sarcocystis kirkpatricki n. sp. (Apicomplexa: Sarcocystidae) in muscles of raccoons (Procyon lotor) from Illinois. J Parasitol. 1990;76:495-500.

13. Stolte M, Odening K, Walter G, Bockhardt I. The raccoon as intermediate host of three Sarcocystis species in Europe. Comp Parasitol. 1996:63:145-9.

14. Kubo M, Okano T, Ito K, Tsubota T, Sakai H, Yanai T. Muscular sarcocystosis in wild carnivores in Honshu. Japan. Parasitol Res. 2009;106:213-9.

15. Dubey JP, Sykes JE, Shelton GD, Sharp N, Verma SK, Calero-Bernal R, et al. Sarcocystis caninum and Sarcocystis svanai n. spp. (Apicomplexa: Sarcocystidae) associated with severe myositis and hepatitis in the domestic dog (Canis familiaris). J Eukaryot Microbiol. 2015;62:307-17.

16. Mugridge NB, Morrison DA, Johnson AM, Luton K, Dubey JP, Votýpka $J$, et al. Phylogenetic relationships of the genus Frenkelia: a review of its history and new knowledge gained from comparison of large subunit ribosomal ribonucleic acid gene sequences. Int J Parasitol. 1999:29:957-72.

17. Gjerde B. Molecular characterisation of Sarcocystis rileyi from a common eider (Somateria mollissima) in Norway. Parasitol Res. 2014;113:3501-9.
18. Rosenthal BM, Dunams DB, Pritt B. Restricted genetic diversity in the ubiquitous cattle parasite, Sarcocystis cruzi. Infect Genet Evol. 2008;8:588-92.

19. Gjerde B. Phylogenetic relationships among Sarcocystis species in cervids, cattle and sheep inferred from the mitochondrial cytochrome c oxidase subunit I gene. Int J Parasitol. 2013;43:579-91.

20. Gjerde B. Sarcocystis species in red deer revisited: with a re-description of two known species as Sarcocystis elongata n. sp. and Sarcocystis truncata n. sp. based on mitochondrial cox1 sequences. Parasitology. 2014;141:441-52.

21. Pavlásek I, Máca O. Morphological and molecular identification of Sarcocystis arctica sarcocysts in three red foxes (Vulpes vulpes) from the Czech Republic. Parasitol Int. 2017;66:603-5.

22. Gjerde B, Vikøren T, Hamnes IS. Molecular identification of Sarcocystis halieti n. sp., Sarcocystis lari and Sarcocystis truncata in the intestine of a white-tailed sea eagle (Haliaeetus albicilla) in Norway. Int J Parasitol Parasites Wildl. 2017;7:1-11.

\section{Publisher's Note}

Springer Nature remains neutral with regard to jurisdictional claims in published maps and institutional affiliations.
Ready to submit your research? Choose BMC and benefit from:

- fast, convenient online submission

- thorough peer review by experienced researchers in your field

- rapid publication on acceptance

- support for research data, including large and complex data types

- gold Open Access which fosters wider collaboration and increased citations

- maximum visibility for your research: over 100M website views per year

At BMC, research is always in progress.

Learn more biomedcentral.com/submissions 